A - preparing concepts

$\mathrm{B}$ - formulating methods

$\mathrm{C}-$ conducting research

$\mathrm{D}$ - processing results

E - interpretation and conclusions

$\mathrm{F}$ - editing the final version

\section{Features of heart rate variability in breast cancer survivors with various types of attitude to the disease}

\section{Cechy zmienności rytmu zatokowego u osób po nowotworze piersi z różnym nastawieniem do choroby}

\author{
Evgen Prystupa ${ }^{1 \mathrm{~A}, \mathrm{~B}}$, Tetiana Odynets ${ }^{2^{\star} \mathrm{C}, \mathrm{D}}$, Yuriy Briskin ${ }^{2 \mathrm{E}}$, \\ Iryna Svistelnyk ${ }^{3 \mathrm{~F}}$ \\ ${ }^{1}$ Department of Theory and Methods of Physical Culture, Lviv State University \\ of Physical Culture \\ 2 Department of Theory of Sport and Physical Culture, Lviv State University \\ of Physical Culture
}

${ }^{3}$ Department of Informatics and Kinesiology, Lviv State University of Physical Culture

\section{Abstract}

Introduction: Surgical treatment and radiotherapy can prolong the life expectancy of women with breast cancer but also might have side effects on heart rate variability. $\mathrm{Cu}-$ rrently breast cancer treatment has contributed to significant improvements in survival rate, but negative effects on the psycho-emotional state and functionality of the autonomic nervous system of these interventions in women is high.

We aimed to investigate the heart rate variability features in breast cancer survivors who have varied attitudes towards the disease.

Material and methods: Heart rate variability analysis, determination of various attitudes towards the disease, and mathematical statistical methods. The survey of 110 breast cancer survivors was conducted utilizing Type of Attitude Toward The Disease questionnaire. The women were executed radical mastectomy and adjuvant radiation treatment for breast cancer. Patients aged between 56 and 60 years.

Results: The results of our study showed that patients with a rational type of attitude towards disease had statistically $(\mathrm{p}<0.05)$ better parameters of heart rate variability. Values of standard deviation of the N-N interval, root mean square of successive differences, total power, high-frequency range, and stress index were much better in patients with rational type of attitude as compared with the women who had intrapsychic and interpsychic attitudes.

Conclusions: These data show that identified features of various attitudes towards the disease in breast cancer survivors clarify the necessity for particular attention to their heart rate variability parameters.

Key words: heart rate, attitude, woman, breast cancer, mastectomy 


\section{Streszczenie}

Wstęp: Leczenie operacyjne oraz radioterapia wydłużają oczekiwaną długość życia $\mathrm{u}$ kobiet $\mathrm{z}$ nowotworem piersi ale mogą również wpływać na zmienność rytmu zatokowego. Obecnie leczenie nowotworów piersi istotnie poprawiło przeżywalność, jednak ma ono znaczny negatywny wpływ na stan psychiczny i emocjonalny oraz funkcjonowanie autonomicznego układu nerwowego u pacjentek.

Celem badań była analiza cech zmienności rytmu zatokowego u osób po nowotworze piersi, które reprezentowały różne nastawienie do choroby.

Materiał $i$ metody: Analiza zmienności rytmu zatokowego, określenie różnych rodzajów nastawienia do choroby oraz matematyczne metody statystyczne. Badanie ankietowe z udziałem 110 osób po nowotworze piersi zostało przeprowadzone z użyciem kwestionariusza „Rodzaj Nastawienia do Choroby” (TATD). Badane kobiety przeszły radykalną mastektomię oraz uzupełniającą radioterapię. Pacjentki były w wieku 56 do 60 lat.

Wyniki: Wyniki naszego badania wykazały, że pacjentki z racjonalnym podejściem do choroby miały statystycznie lepsze $(\mathrm{p}<0.05)$ parametry zmienności rytmu zatokowego. Wartości SDNN, średniej kwadratowej kolejnych różnic, mocy całkowitej, wysokiego zakresu częstotliwości oraz wskaźnika stresu były znacznie lepsze u pacjentek z racjonalnym podejściem niż u kobiet z podejściem intrapsychicznym lub interpsychicznym.

Wnioski: Powyższe dane wskazują, że określone cechy różnych typów nastawienia do choroby u osób po nowotworze piersi uzasadniają konieczność zwrócenia szczególnej uwagi na ich parametry zmienności rytmu zatokowego.

Słowa kluczowe:

rytm serca, nastawienie, kobieta, nowotwór piersi, mastektomia

\section{Introduction}

Surgical treatment and radiotherapy can prolong the life expectancy of women with breast cancer but also might have side effects on heart rate variability [1]. Currently breast cancer treatment has contributed to significant improvements in survival rate, but negative effects on the psycho-emotional state and functionality of the autonomic nervous system of these interventions in women is high. [2,3]. These women may present with psychological distress, mood disturbances, adverse emotion, anxiety, depression, phobia, sadness, and decreased selfconfidence resulting from a negative body image. Negative complications from the tumor itself and methods of therapy may result in significant problems in the psycho-emotional state and the functionality of the autonomic nervous system [4-6].

Analysis of heart rate parameters is a valid and informative tool for autonomic dysfunction detection in breast cancer survivors by quantitative and qualitative analysis of heart rhythm [7-9].

Previous studies have demoinstrated that breast cancer survivors present with dysfunction of the autonomic nervous system and neurohumoral regulation [9-12].
With a view to improve functional capabilities of the autonomic nervous system to a stressful situation and to individualize the rehabilitation program depending on the heart rate variability features in breast cancer survivors with various attitudes towards the disease, this calls for performing psychotherapy during the treatment and after completion of therapy.

Taking into consideration the possible relationship of psycho-emotional state and heart rate variability, individual peculiarities of a woman's personality and attitudes towards the disease, there is an urgent need to investigate the heart rate parameters in breast cancer survivors with various attitudes towards this disease.

\section{Materials and methods}

The research was performed at the Khortytsia National Academy (Ukraine) between February $21^{\text {th }}, 2014$ and June $18^{\text {th }}, 2016$. The study was in full compliance with the Helsinki Declaration and approved by Ethical Committee of Khortytsia National Academy. Women were informed about the purpose of the study and provided written consent before study implementation. 
110 women with breast cancer were recruited into this study. All patients underwent a radical mastectomy and adjuvant radiation treatment for stage I-II breast cancer. Patients awereged between 56 and 60 years.

The method of determining individual's attitude toward the disease was based on information about their relationship to a number of the most significant life problems and situations related to the disease. Participants completed Type of Attitude Toward The Disease questionnaire that combined various cases of relation to treatment, closely related people, medical staff, assignments, activity, etc. [13].

Based on the survey results, three groups based on attitudes toward the disease were formed. The first one included a rational type of attitude to the disease (harmonious, ergopathic and anozognozyc types), which point out at the most favorable patient's concern to the disease; the second one (intrapsychic attitude) composed of anxious, hypochondriac, neurasthenic, melancholic, apathetic ones, which indicated about disorders of social adaptation of patients; the third one (interpsychic attitude) included sensitive, self-centered, paranoid and dysphoric types, which frequently identified with patterns of mental and social disadaptation.

The assessment of heart rate variability provides information about the functional state of all regulation stages of human life in normal and with various pathologies. The heart rate as a component of multimetric interaction that reacts to any changes in homeostasis, and its physiological parameters can objectively reflect the state of the organism.
The following indicators were calculated within 6 months of mastectomy for treatment of breast cancer: standard deviation of the normal-to-normal intervals (SDNN), square root of the mean of the sum of the squares of differences between adjacent NN intervals (RMSSD), very low frequency power (VLF), low frequency power (LF), high frequency power (HF), total power (TP), LF/HF ratio, stress index (Si). Heart rate was recorded in the 2 nd indirect lead. Heart rate variability characteristics were evaluated from shortterm 5-minute recordings [14].

Analysis of results were performed using Statistica and by analyzing descriptive statistics (mean, and standard error of the mean). T-test for independent samples was used to analyze heart rate variability indicators between the women with rational type of attitude to the disease and intrapsychic attitude, and with rational type and interpsychic attitude. Statistically significant results were considered in the case $\mathrm{p}<0.05-0.001$.

\section{Results}

Demographic and treatment-related characteristics of study participants with Different Types of Attitude to the Disease are presented in Table 1. These data demonstrsted that a majority of the breast cancer survivors presented with the rational type of attitude towards the disease $(48 \%, \mathrm{n}=53)$ as compared to those with intrapsychic $(36 \%, \mathrm{n}=40)$ and interpsychic $(16 \%, \mathrm{n}=17)$ attitudes at outpatient treatment stage.

Tab. 1. Demographic and treatment-related characteristics of study participants with Different Types of Attitude to the Disease

\begin{tabular}{|c|c|c|c|}
\hline Characteristics & $\begin{array}{c}\text { Rational } \\
\text { attitude }(\mathrm{n}=53)\end{array}$ & $\begin{array}{c}\text { Intrapsychic } \\
\text { attitude }(\mathrm{n}=40)\end{array}$ & $\begin{array}{l}\text { Interpsychic } \\
\text { attitude }(\mathrm{n}=17)\end{array}$ \\
\hline Age, $(\mathrm{M} \pm \mathrm{m})$ & $57.44 \pm 2.16$ & $57.99 \pm 2.24$ & $58.11 \pm 1.97$ \\
\hline \multicolumn{4}{|l|}{ Race: } \\
\hline White, n (\%) & $52(98 \%)$ & $38(95 \%)$ & $16(94 \%)$ \\
\hline Black, n (\%) & $1(2 \%)$ & $2(5 \%)$ & $1(6 \%)$ \\
\hline Married/committed relationship, $\mathrm{n}(\%)$ & $45(85 \%)$ & $27(68 \%)$ & $7(41 \%)$ \\
\hline High school graduate, $\mathrm{n}(\%)$ & $40(75 \%)$ & $18(45 \%)$ & $6(35 \%)$ \\
\hline College graduate, $\mathrm{n}(\%)$ & $10(19 \%)$ & $20(50 \%)$ & $10(59 \%)$ \\
\hline Post-graduate, n (\%) & $3(6 \%)$ & $2(5 \%)$ & $1(6 \%)$ \\
\hline Body mass index, $\mathrm{kg} / \mathrm{m}^{2},(\mathrm{M} \pm \mathrm{m})$ & $25.72 \pm 0.34$ & $26.01 \pm 0.81$ & $26.11 \pm 0.52$ \\
\hline \multicolumn{4}{|l|}{ Treatment: } \\
\hline Surgery type (mastectomy by Madden), n (\%) & $53(100 \%)$ & $40(100 \%)$ & $17(100 \%)$ \\
\hline Time after surgery, months & $5.27 \pm 0.32$ & $5.12 \pm 0.42$ & $5.32 \pm 0.42$ \\
\hline \multicolumn{4}{|l|}{ Cancer Stage: } \\
\hline Stage $1, \mathrm{n}(\%)$ & $15(28 \%)$ & $11(28 \%)$ & $4(23 \%)$ \\
\hline Stage $2, \mathrm{n}(\%)$ & $38(72 \%)$ & $29(72 \%)$ & $13(77 \%)$ \\
\hline
\end{tabular}


Analysis of the heart rate variability indicators between breast cancer survivors with the three forms of attitude to the disease are shown in Table 1. As it can be seen from Table 1, the average results of the SDNN were significantly higher in women with a rational attitude toward their breast cancer as compared to those with intrapsychic and interpsychic attitudes by $4.62 \mathrm{~ms}(\mathrm{p}<0.05)$ and $4.30 \mathrm{~ms}(\mathrm{p}<0.05)$, respectively. This pattern of more normalized values in the indicies of heart rate variability in those woman presenting with a rational attitude was observed for RMSSD, TP and HF.

Tab. 2. Comparison of Heart Rate Variability Indicators $(\mathrm{M} \pm \mathrm{m})$ in Breast Cancer Survivors with Different Types of Attitude to the Disease

\begin{tabular}{|c|c|c|c|}
\hline Indicator & $\begin{array}{c}\text { Rational } \\
\text { attitude }(\mathrm{n}=53)\end{array}$ & $\begin{array}{c}\text { Intrapsychic } \\
\text { attitude }(\mathrm{n}=40)\end{array}$ & $\begin{array}{c}\text { Interpsychic } \\
\text { attitude }(\mathrm{n}=17)\end{array}$ \\
\hline $\mathrm{SDNN}(\mathrm{ms})$ & $27.66 \pm 1.33$ & $23.04 \pm 1.21^{*}$ & $23.36 \pm 1.07 \bullet$ \\
\hline $\mathrm{RMSSD}(\mathrm{ms})$ & $22.69 \pm 1.61$ & $17.20 \pm 1.37^{*}$ & $532.77 \pm 1.05 \bullet$ \\
\hline $\mathrm{TP}\left(\mathrm{ms}^{2}\right)$ & $707.88 \pm 71.94$ & $696.68 \pm 86.84$ & $215.61 \pm 30.36$ \\
\hline $\mathrm{VLF}\left(\mathrm{ms}^{2}\right)$ & $175.38 \pm 32.29$ & $268.28 \pm 50.51$ & $191.61 \pm 22.50$ \\
\hline $\mathrm{LF}\left(\mathrm{ms}^{2}\right)$ & $252.48 \pm 28.47$ & $236.24 \pm 40.83$ & $125.49 \pm 24.74 \bullet \bullet$ \\
\hline $\mathrm{HF}\left(\mathrm{ms}^{2}\right)$ & $280.02 \pm 31.92$ & $192.16 \pm 25.32^{*}$ & $2.39 \pm 0.31$ \\
\hline $\mathrm{LF} / \mathrm{HF}$ (c.u.) & $1.80 \pm 0.22$ & $1.58 \pm 0.32$ & $390.72 \pm 29.44 \bullet \bullet$ \\
\hline $\mathrm{Si}$ (c.u.) & $277.75 \pm 19.80$ & $379.44 \pm 23.86^{* *}$ & \\
\hline
\end{tabular}

However, the average values of $\mathrm{Si}$ were lower in patients with rational attitude toward disease as compared with the women with intrapsychic and interpsychic attitudes by 101.69 c.u. $(\mathrm{p}<0.01)$ and 112.97 c.u. $(\mathrm{p}<0.01)$, respectively.

\section{Discussion}

The results of previous studies have confirmed $[2,3,10,15]$ that a fundamental part of the psychological disadaptation in breast cancer survivors is the psychological effect of surgical treatment that lead to organ removal or to cosmetic defects precipiation.

In most cases, the structure of the heart rate variability in woman with intrapsychic and interpsychic attitudes to the disease is described by disbalance of parasympathetic and sympathetic parts of the autonomic nervous system, rigidity of rhythm and its switching from the faster reflex level to lower hormonal and metabolic level, that are not able for quick homeostasis regulation. High values of $\mathrm{Si}$ in such women indicate about psychologic stress, tension mechanisms of adaptation to the action of external and internal factors.

Previous studies $[6,11,12]$ have presented that autonomic dysregulation in women with breast cancer is closely connected with anxiety, depression, and sleep disturbances. Physical activity using lowintensity aerobic load and strengthening exercises is able to improve the functioning of the vegetative nervous system in breast cancer survivors
The results of the current study indicate that women with disadaptive cases of attitude to the disease have reduced indicies of heart rate variability, which might significantly impair their adaptation processes to physical activity.

The results obtained in this study support the conclusion that future physical interventions must be individualized taking into account the type of attitude that is adopted towards the disease by the breast cancer survivor.

\section{Conclusions}

These data show that identified features of various attitudes towards the disease in breast cancer survivors clarify the necessity for particular attention to their heart rate variability parameters. Values of SDNN interval, RMSSD, TP, HF, and Si were much better in patients with rational type of attitude as compared with the women who had intrapsychic and interpsychic attitudes. 


\section{References}

1. Caro-Morán E, Fernández-Lao C, Galiano-Castillo N, Cantarero-Villanueva I, Arroyo-Morales M, Díaz-Rodríguez L. Heart Rate Variability in Breast Cancer Survivors After the First Year of Treatments: A Case-Controlled Study. Biol Res Nurs. 2016 Jan;18(1):43-9. doi: 10.1177/1099800414568100.

2. Desautels C, Savard J, Ivers H, Savard MH, Caplette-Gingras A. (2018). Treatment of Depressive Symptoms in Patients with Breast Cancer: A Randomized Controlled Trial Comparing Cognitive Therapy and Bright Light Therapy. Health Psychol. 2018;37(1):1-13. doi: 10.1037/hea0000539

3. González-Fernández S, Fernández-Rodríguez C, Mota-Alonso MJ, García-Teijido P, Pedrosa I, Pérez-Álvarez M. Emotional state and psychological flexibility in breast cancer survivors. Eur J Oncol Nurs. 2017;30:75-3. doi: 10.1016/j.ejon.2017.08.006.

4. Blaney JM, Lowe-Strong A, Rankin-Watt J, Campbell A, Gracey JH. Cancer survivors' exercise barriers, facilitators and preferences in the context of fatigue, quality of life and physical activity participation: a questionnaire-survey. Psychooncology. 2013;22(1):186-94.

5. Arab C, Dias DP, Barbosa RT, Carvalho TD, Valenti VE, Crocetta TB, Ferreira M, et al. Heart rate variability measure in breast cancer patients and survivors: a systematic review. Psychoneuroendocrinology. 2016 Jun;68:57-8. doi: 10.1016/j.psyneuen.2016.02.018.

6. Maass SW, Roorda C, Berendsen AJ, Verhaak PF, de Bock, GH. The prevalence of long-term symptoms of depression and anxiety after breast cancer treatment: A systematic review. Maturitas. 2015;82(1):100-8. doi: 10.1016/j.maturitas.2015.04.010.

7. Taralov Z, Terziyski K, Kostianev S. Heart rate variability as a method for assessment of the autonomic nervous system and the adaptations to different physiological and pathological conditions. Folia Med (Plovdiv). 2015;57(3-4):173-80; doi: 10.1515/ folmed-2015-0036.

8. Crosswell AD, Lockwood KG, Ganz PA, Bower JE. Low heart rate variability and cancer-related fatigue in breast cancer survivors. Psychoneuroendocrinology. 2014 Jul;45:58-66. doi: 10.1016/j.psyneuen.2014.03.011.

9. Guo Y, Koshy S, Hui D, Palmer JL, Shin K, Bozkurt M, Yusuf SW. Prognostic Value of Heart Rate Variability in Patients With Cancer. J Clin Neurophysiol. 2015 Dec;32(6):516-20. doi:10.1097/WNP.0000000000000210.

10. Briskin Y, Odynets T, Pityn M. Influence of the problem-oriented program of physical rehabilitation on the type of attitude to the disease in women with postmastektomy syndrome. Journal of Physical Education and Sport. 2016;16(1):33-7. doi:10.7752/jpes.2016.01006.

11. Reis A, Garcia JB, Diniz R, Silva-Filho AC, Dias CJ, Leite RD, Mostarda C. Effect of exercise training and detraining in autonomic modulation and cardiorespiratory fitness in breast cancer survivors. J Sports Med Phys Fitness. 2017;57(7-8):1062-68. doi: 10.23736/S0022-4707.17.07012-8.

12. Shin H, Yang J, Kim S. Effects of circuit exercise on autonomic nerve system of survivors after surgery of breast cancer. J Phys Ther Sci. 2016;28(10):2898-903. doi:10.1589/jpts.28.2898.

13. Wasserman LI, Iovlev BV, Karpova EB, Vuks AA. Psychological diagnosis of the attitude to disease. Sankt-Peterburgskiy nauchno-issledovatelskiy psihonevrologicheskiy institut im. V.M. Behtereva; 2005 [in Russian].

14. Heart rate variability. Standards of measurement, physiological interpretation, and clinical use. Task Force of the European Society of Cardiology and the North American Society of Pacing and Electrophysiology. Eur. Heart. J. 1996;17(3):354-381.

15. Yi JC, Syrjala KL. Anxiety and Depression in Cancer Survivors. Med Clin North Am. 2017;101(6):1099-113. doi: 10.1016/ j.mena.2017.06.005. 